\title{
IAMJ
}

INTERNATIONAL

AYURVEDIC

MEDICAL JOURNAL

ISSN: 23205091

Impact Factor: 5.344

\section{A CASE STUDY TO EVALUATE THE EFFICACY OF KAL BASTI FOLLOWED BY PANCHATIKTA KSHEER SARPI BASTI IN THE MANAGEMENT OF ASTHIMAJJAGAT VATA WITH SPECIAL REFERENCE TO HLA-B27 (ANKYLOSING SPONDYLITIS)}

\author{
Seema Bahatkar' ${ }^{1}$ Anita A. Patil², Kesar N. Kshirsagar ${ }^{3}$ \\ ${ }^{1}$ HOD, Panchakarma Department, R. A. Podar Medical (Ayu) College, Worli, Mumbai-18, Maharashtra, India \\ ${ }^{2}$ Associate Professor, Panchakarma Department, R. A. Podar Medical (Ayu) College, Worli, Mumbai-18, \\ Maharashtra, India \\ ${ }^{3}$ MD-Scholar, $3^{\text {rd }}$ yr, Panchakarma Department, R. A. Podar Medical (Ayu) College, Worli, Mumbai-18, \\ Maharashtra, India
}

Corresponding Author: kesarkshirsagar@gmail.com

\section{https://doi.org/ $10.46607 /$ iamj4308082020}

(Published online: August 2020)

Open Access

(C) International Ayurvedic Medical Journal, India 2020

Article Received: 17/07/2020 - Peer Reviewed: 14/08/2020 - Accepted for Publication: 14/08/2020

Check for updates

\begin{abstract}
Ankylosing spondylitis belongs to group of Rheumatic disease known as spondyloarthropathies which show a strong association with genetic marker HLA-B27. Whereas the incidence of HLA-B27 is less than 1 percent in general population, it is present in more than $85 \%$ of patients with ankylosing spondylitis. Inflammatory back pain and stiffness are prominent early in the disease whereas chronic aggressive disease may produce pain and marked axial immobility and deformity. HLA-B27 is the most common findings in Ankylosing Spondylitis. In Ayurveda, no typical nomenclature has been found for the said disease but considering all sing and symptom of the patients, it can be treated as Asthimajjagata vata. No satisfactory treatment is available in modern medicine for this disorder. Various Panchakarma procedures and Ayurvedic drugs have been proved useful for these manifestations. The patient was considered suffering from Asthimajjagat Vata (HLA-B27) and was treated with Guduchi, Dashamool and Erandmool as Niruha and Bala-guduchyadi Tail as Anuvasana for 16 days as Kal basti followed by Panchatikta
\end{abstract}


ksheera sarpi Basti for 14 days (1 month) was given. Patients condition was assessed for symptoms of Asthimajjagat Vata (HLA-B27 positive). This study shows successfully managed with Ayurvedic treatment.

Keywords: Asthimajjagat Vata, Kal Basti, Panchatikta ksheer Sarpi Basti, HLA-B27 (Ankylosing spondylitis).

\section{INTRODUCTION}

Ankylosing spondylitis is a chronic inflammatory disorder that primarily involves the sacroiliac joints and the axial skeleton. There is also a variable involvement of peripheral joints and articular structures. Musculoskeletal pain, stiffness, and immobility of spine due to AS is a major burden. Prevalence of AS in India is $0.03 \%$ as per surveys conducted by Bone and Joint Decade India from 2004 to $2010{ }^{(1)}$ Late adolescence or early adulthood, before the age group of 40 years, and the male patients are mostly affected than female in the

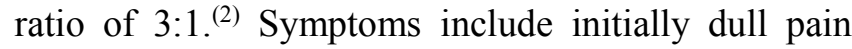
deep in the lower back i.e. in lumbar or gluteal region accompanied with morning stiffness improving with activities are found commonly in cost sternal junctions, spinous process, iliac crest, great trochanters, ischial tuberosities, tibial tubercles, and heel. Though the exact nomenclature of the disease is not available in Ayurvedic text, considering Chakraman kastata (pain during walking), Kati shool \& stambha (back pain and stiffness), Ubhay pad shool (pain in both legs), Bala kshaya (decrease vitality and strength) etc, it can be considered as Asthimajjagata vata. ${ }^{(3)}$

The manifestation of Vata Vyadhi (different disease due to Vata dosha) is prominent in fully established AS. In AS, the ethereal fibrocartilage is the major target of the immune system, and there may be destructive synovitis. The myxoid subchondral bone marrow is mainly affected. There is the destruction of nearby articular tissues or joint tissues as disease progresses. The new original cartilages are replaced by bone through fusion. This causes fusion of the joint bones that causes stiffness and immobility. In Ankylosing spondylitis, the spine becomes progressively ankylosed, Spinal rigidity and secondary Osteoporosis Predispose to spinal fracture, presenting as acute, severe, well, localised pain (Boon Nicholas et al., 2006). Ayurveda interprets these changes as vitiated Vata dosha that affect Asthi dhatu (bones). We present a case that was successfully treated on the line of Ayurvedic management of $A s$ thimajjagata vata (vata disorder involving bone and bone marrow). Basti karma is one among the best treatment for Vata disorders. Chakrapani on commenting explains that when we nourish the root whole plant will be nourished. In this regard the process of stiffness and degeneration can be successfully treated by Basti. The aim of treatment is to relieve pain and stiffness, maintain maximum range of skeletal mobility and avoid deformity. ${ }^{(4)}$ Therefore, it was selected for the present case. So, this case report is planned to evaluate the effect of Kal Basti followed by Panchatikta Ksheer Sarpi Basti in the management of Asthimajjagata vata w.s.r. to HLA-B27 (Ankylosing spondylitis). Here Basti therapy can be highly beneficial and it can prevent further progressive of illness.

Aim: To evaluate the effect of Kal Basti Followed by Panchatikta ksheer Sarpi Basti in Asthimajjagata vata w.s.r. to HLA-B 27 (Ankylosing Spondylitis).

\section{Methodology}

\section{Case Report}

Name of Patient- XYZ, Age- 19 yr./Male, OccupationStudent., Reg. OPD No. -54270 , Reg. IPD No. -3257 , DOA - 23/10/2019 DOD - 25/11/2019

\section{Brief History of Case}

A 19-year-old male patient complaining of Kati shool \& stambha (back pain and stiffness), Ubhay pad shool (pain in both legs), Chakraman kastata (pain during walking), Bala kshaya (decrease vitality and strength) for 2 months. He took allopathic treatment like steroids, painkiller, calcium supplements for past 2 months but didn't get any relief. When he was taking medicine that time, he felt relief but after stopped medicine his pain again increased more than before. So, for further management he came to Panchakarma OPD No. 15 of R. A. Podar Hospital Worli, Mumbai. 


\section{Diagnosis and Assessment.}

HLA-B27 (Ankylosing spondylitis) was diagnosed and assessed as follows. Low back pain and stiffness (Katishool \& graha) - VAS method was used to assess the pain., Pain in both legs (Ubhay Pad Shool) - Assessed by asking present or absent., Difficulty in Straight Leg Rising (Sakashta Padothankriya) - has been assessed by SLR test., Decreased vitality and strength ( $\mathrm{Bal}$ kshaya)- has been assessed by weight and asking present or absent.

\section{Observation}

Gait- slow and patient has pain after walking., Prakriti - Vatakaphaj., Vaya - Tarun, Bala - Alpa, Agni - Vishamagni, Koshta - Madhym koshta

The Causative factors are Aahar - Akalaj bhojan, Kwachit paryusheet annasevan, Mansahar, Pav-Butter, Chaha-Bread, Ati katu rasatmak aahar sevan., Vihar - Long-time sitting work (for study), AC work, Driving., Dosha - Vatakaphaj, Dushya - Asthi,Majja,Mansa., Strotodushti - Asthivaha, Majjavaha Adhisthan - Katitrik Sandhi, Udbhavasthan - Pakvashaya.

\section{Treatment Given}

\section{Kal Basti Krama for 16 days}

Ingredients of the Kal Basti as Niruha are Guduchi, Erand mool, Dashmoola. The preparation of Niruha Basti was done in the usual manner of Niruha Basti. Til taila $80 \mathrm{ml}$ and Madhu $30 \mathrm{ml}$ add together and mixed well then add Saindhava 5 gm to it and mixed well. Lastly decoction $550 \mathrm{ml}$ was added to it. The mixture is then filtered through sieve. Total quantity will be $650 \mathrm{ml}$ should be taken, and the Basti was given at 7.30 am in empty stomach. For Anuvasana Basti Balaguduchayadi Taila $100 \mathrm{ml}$ has been used, and the total quantity were taken is $100 \mathrm{ml}$, and the time of administration was $12.30 \mathrm{Pm}$, and this procedure were performed after food.

Panchatikta ksheera sarpi Basti given for 14 days. (after Kal basti)

Panchatikta Ksheer Sarpi Basti ${ }^{(7)} 100 \mathrm{ml}$ Decoction of Panchatikta Dravyas was made., $100 \mathrm{ml}$ of Godugdha was added and the siddha Ksheer was prepared., Preparation of basti: Siddhaksheer $100 \mathrm{ml}+$ Panchatikta ghrita $20 \mathrm{ml}$., Total $120 \mathrm{ml}$ of Panchatikta Kheer Sarpi Basti was given for 7 days., Basti was administered \& Basti Pratyahara Kala was noted.

Table 1: Basti Schedule, one course of Kala Basti Administrated as per the schedule that is

\begin{tabular}{|l|l|l|l|l|l|l|l|l|l|l|l|l|l|l|l|l|}
\hline Day & 1 & 2 & 3 & 4 & 5 & 6 & 7 & 8 & 9 & 10 & 11 & 12 & 13 & 14 & 15 & 16 \\
\hline Basti & A & N & A & N & A & N & A & N & A & N & A & N & A & A & A & A \\
\hline
\end{tabular}

$\mathrm{A}-$ Anuvasan* $^{\mathrm{N}}-$ Niruha*

Table 2: Basti Schedule, Panchatikta Ksheera Sarpi Basti Administrated as per the schedule that is

\begin{tabular}{|l|l|l|l|l|l|l|l|l|l|l|l|l|l|l|}
\hline Day & 1 & 2 & 3 & 4 & 5 & 6 & 7 & 8 & 9 & 10 & 11 & 12 & 13 & 14 \\
\hline Basti & $\mathrm{P}$ & $\mathrm{P}$ & $\mathrm{P}$ & $\mathrm{P}$ & $\mathrm{P}$ & $\mathrm{P}$ & $\mathrm{P}$ & $\mathrm{P}$ & $\mathrm{P}$ & $\mathrm{P}$ & $\mathrm{P}$ & $\mathrm{P}$ & $\mathrm{P}$ & $\mathrm{P}$ \\
\hline
\end{tabular}

P - Panchatikta Ksheera Sarpi Basti*

\section{Result}

The results observed after the treatment were. Improvement was seen in sign and symptoms of the patient. Relief was (near about $80 \%$ ) found in Low back pain \& stiffness, Ubhay pad shool, Chakraman kashtata, Bala kshaya. Stiffness of lumbosacral joint (Katitrik sandhigraha) has gone. Gait has improved. 
Table 3: Observation

\begin{tabular}{|l|l|l|}
\hline Observation & Before Treatment & After Treatment \\
\hline Walking distance & $\begin{array}{l}\text { Patient had severe pain after walking 100 } \\
\text { mts. }\end{array}$ & Patient could easily walk without pain about 400 mts. \\
\hline Walking time & $\begin{array}{l}\text { Patient took around 10 minutes to walk 100 } \\
\text { steps. }\end{array}$ & Patient took around 3 minutes to walk 100 steps. \\
\hline SLRT & $\begin{array}{l}\mathrm{Rt}-30^{0} \\
\mathrm{Lt}-30^{\circ} \\
\mathrm{B} / \mathrm{L}-0^{0}\end{array}$ & $\begin{array}{l}\mathrm{Rt}-90^{0} \\
\mathrm{Lt}-90^{\circ} \\
\mathrm{B} / \mathrm{L}-90^{\circ}\end{array}$ \\
\hline Weight & $46 / \mathrm{kg}$ & $48 / \mathrm{kg}$ \\
\hline
\end{tabular}

\section{DISCUSSION}

The case was treated on the line of management of $A s$ thimajjagata vata. The established treatment included steroids \& analgesics along with physiotherapy having limited prognosis. Basti being the most widely used and highly effective treatment modality in Panchakarma. Though basti is mentioned in vitiation of all the Vata, Pitta, Kapha, and Rakta Doshas. ${ }^{(20)}$ In this study, Kal basti was given for 16 days, as Niruha which contain Guduchi, erandamool, dashamool. Guduchi has property of dipana, pachana, vedanasthapana (pain relieving action), tridoshahar (to pacify all three doshas) and rasayana (rejuvenate). Dashmoola act as shothahara (anti-inflammatory), Tridoshahara (to pacify all three doshas) and Vedanasthapana. Erandamool possesses Ushna, guru, Sara, Teekshna, sukshma, picchila and visra guna. It is having Katu, Kashaya, Madhura and Tikta rasa and Madhura vipaka. The action of Erand moola is Strotovishodhana (clearing all channels), Lekhana, Deepana, balya and Rasayana. It has Vatashleshmahara effect and effective in condition like Jangha, Kati, Anaha and Vibandha. Thus, it effective in the management of Kati shool and stambha, ubhay pad shool, chakraman kastata. Mode of action of Balaguduchyadi taila, it is indicated in all types of Vatakapha Pradhan vyadhi. It is highly efficient to reduce Vata and increase vitality and strength. Aacharya Charak states Basti $1^{\text {st }}$ act on Pakawashaya and keep the Vata in Samavastha. It produces Chedana of Vata. So all the Vata Vikaras will be diminished just like the tree which is cut by its root loses the extremities, stem, Shaka, Kanda, Pushpa etc. ${ }^{(21)}$ Aacharya Charaka has said that in the diseases related to Asthi and Majja we should give Basti using Tikta Rasatmaka Aushadhi
Dravya along with Ghrut and Ksheer. ${ }^{(22)}$ As the Aacharya Dalhana has said Asthidhara Kala is Purishadhara kala. ${ }^{(23)}$ Purishadhara kala is nothing but Pakvashaya (large intestine). "Pakvashaya" is very important Sthan (Site) of Vata Dosha. ${ }^{(24)}$ Here there is Nirmiti (origin) of Vata Dosha and Asthi dhatu. ${ }^{(25)}$ Tikta Rasa has Shothaghna (anti-oedematous and anti-inflammatory) and Pittahara properties (suppression and elimination of vitiated Pitta dosha). ${ }^{(26)}$ The substance having Snigdha and Shoshana (drying) properties and produces Kharatwa (roughness) increases Asthi, as Asthi is also Khara by nature. But no substance is available that has both Snigdha and Shoshana properties. So Ksheer and Ghrut which are Snigdha in nature are advice to be used together in the form of Ksheera Basti. This combination has ability to reduce Kharatwa. Hence it can be said that Tikta Ksheer Sarpi Basti has ability to repair degeneration of bones and cartilage. ${ }^{(27)}$ This treatment proved significant in relieving symptoms such as pain with walking, restricted movement of joints and increase vitality and strength.

Drug delivered at the upper part of the rectum is absorbed from the upper rectal mucosa and is carried by the Superior mesenteric vein into the portal circulation, and the drug absorbed from the lower part of the rectum enters directly into systemic circulation via middle and inferior haemorrhoid veins and hence the drug is available in the circulation for immediate action.

\section{CONCLUSION}

In the case study we got good results of Basti karma. The treatment given for Asthimajjagata vata was Kal Basti (Niruha-guduchi, dashamool, erandmool Basti \& Anuvasana- Bala-guduchyadi taila) followed by 
Panchatikta Ksheer Sarpi Basti. Which helped in Vatadosha shaman, relief in symptoms of disease and also an attempt to provide safe and effective treatment to the patient. Kal Basti \& Panchatikta ksheera sarpi Basti schedule result in complete relief and provide excellent improvement in clinical sign and symptoms of $A s$ thimajjagata vata. It also provided comparatively better relief in SLR test, walking distance and walking time, weight. But this study needs further evaluation on large number of patients to conclude this treatment.

\section{ACKNOWLEDGEMENTS}

I would like to acknowledge M. A. Podar Hospital Worli, Mumbai for encouragement and providing all necessary facilities to conduct this study.

\section{REFERENCES}

1. Chopra A, Disease burden of rheumatic diseases in India: COPCORD perspective. Indian J Rheumatol cols: 10: 70-7.

2. Taurog joel D., Lipsky peter E., Harrisons Principles of Internal Medicine, volume-2, $14^{\text {th }}$ edition. 1998.

3. Pandey G., editor. Pt. Kashinath Sastri Vidhyaotini Hindi Commentarator of Charaka Samhita of Agnivesa vol 2. Chaukuma Sanskrit Sansthan; Varanasi : 2006. P. 782. (Chikitsa Sthan Vatavyadhi Chikitsa Adhyaya Ch. 28, ver, 33.

4. Editor Nicholas A Boon, Nicki R. Collledge, Brain R Walker, John A. A. Hunter (2006), Davidsons Principle and practice of Medicine $20^{\text {th }}$ Edition, Charchill Livingstone, Elsevier, Page no- 1108.

5. Prof. P. V. Sharma; Dravyaguna Vidyana Volume - II; Chaukhambha Bharati Academy Varanasi; Reprint 2015; pg.no.761-763.

6. Prof. P. V. Sharma; Dravyaguna Vidyana Volume - II; Chaukhambha Bharati Academy Varanasi; Reprint 2015; pg.no. 58-62.

7. Prof. P. V. Sharma; Dravyaguna Vidyana Volume - II; Chaukhambha Bharati Academy Varanasi; Reprint 2015; pg.no. 445-458.

8. Prof. P. V. Sharma; Dravyaguna Vidyana Volume - II; Chaukhambha Bharati Academy Varanasi; Reprint 2015; pg.no. 225-228.

9. Prof. P. V. Sharma; Dravyaguna Vidyana Volume - II; Chaukhambha Bharati Academy Varanasi; Reprint 2015; pg.no. 221-223.
10. Prof. P. V. Sharma; Dravyaguna Vidyana Volume - II; Chaukhambha Bharati Academy Varanasi; Reprint 2015; pg.no. 223-225.

11. Prof. P. V. Sharma; Dravyaguna Vidyana Volume - II; Chaukhambha Bharati Academy Varanasi; Reprint 2015; pg.no. 469-471.

12. Prof. P. V. Sharma; Dravyaguna Vidyana Volume - II; Chaukhambha Bharati Academy Varanasi; Reprint 2015; pg.no. 820-821.

13. Prof. P. V. Sharma; Dravyaguna Vidyana Volume - II; Chaukhambha Bharati Academy Varanasi; Reprint 2015; pg.no. 822-823.

14. Prof. P. V. Sharma; Dravyaguna Vidyana Volume - II; Chaukhambha Bharati Academy Varanasi; Reprint 2015; pg.no. 632-634.

15. Prof. P. V. Sharma; Dravyaguna Vidyana Volume - II; Chaukhambha Bharati Academy Varanasi; Reprint 2015; pg.no. 282-284.

16. Prof. P. V. Sharma; Dravyaguna Vidyana Volume - II; Chaukhambha Bharati Academy Varanasi; Reprint 2015; pg.no. 280-282.

17. Prof. P. V. Sharma; Dravyaguna Vidyana Volume - II; Chaukhambha Bharati Academy Varanasi; Reprint 2015; pg.no. 241-244.

18. Prof. P. V. Sharma; Dravyaguna Vidyana Volume - II; Chaukhambha Bharati Academy Varanasi; Reprint 2015; pg.no. 149-152.

19. Prof. P. V. Sharma; Dravyaguna Vidyana Volume - II; Chaukhambha Bharati Academy Varanasi; Reprint 2015; pg.no. 697-699.

20. Ambikadatta Shastri SUSHRUTA SAMHITA; Ayurveda Tattva- Sandipika, Hindi Commentary, Chaukhamba Sanskrut Sansthan Varanasi, Reprint Edition; 2005, Chapter No. 35 Shlok No. 6.

21. Charaka Samhita Siddhi Sthana, 1/27-34, edited by Vaidya Yadavaji Trikamaji Acgharya, $2^{\text {nd }}$ edition, Varanasi, Chaukhamba Sanskrit Sanstan, 2008 Page no.159.

22. Charaka Samhita, Hindi Commentary, Edited by Dr Bramhanand Tripathi, Chaukhamba Surabharati Prakashan, Varanasi, Edition: 2007, vol 2, Page no 550, Sutrasthana Chapter No. 28, shlok no.27.

23. Sushruta Samhita, Edited by Vaidya Yadavaji Trikamaji Acharya \& Narayan Ram Acharya, Chaukhamba Sanskrit Pratisthan, Reprint: 2014, Page no. 574, Kalpasthana, Chapter No. 4 Shlok no.40.

24. Asthanga Hridyaya, Edited by Hari Sadasiva Sastri Paradakara, Reprint: 2010, Page no. 192. Sutrasthana, Chapter No. 12, Shlok no.1. 
25. Charaka Samhita, Hindi Commentary, Edited by Dr Bramhanand Tripathi, Chaukhamba Surabharati Prakashan, Varanasi, Edition: 2007, vol 2, Page no 937, Chikitsasthana Chapter No. 15, shlok no 14.

26. Singh SK, Rajoria K, Ayurvedic approach in the management of Spinal Cord injury: a case study. Anc Sci Life 2015; 34: 230-4.

27. Charaka Samhita, Hindi Commentary, Edited by Dr Bramhanand Tripathi, Chaukhamba Surabharati Prakashan, Varanasi, Edition: 2007, vol 2, Page no 1169, Sidddhisthan, Chapter No.1, shlok no.40.

\section{Source of Support: Nil}

\section{Conflict of Interest: None Declared}

How to cite this URL: Kesar N. Kshirsagar et al: A Case Study To Evaluate The Efficacy Of Kal Basti Followed By Panchatikta Ksheer Sarpi Basti In The Management Of Asthimajjagat Vata With Special Reference To Hla-B27 (Ankylosing Spondylitis). International Ayurvedic Medical Journal \{online\} 2020 \{cited August, 2020\} Available from: http://www.iamj.in/posts/images/upload/4291_4296.pdf 